Gurzhii Taras, Doctor of Sciences (Law), Professor, Kyiv National University of Trade and Economics, 19, Kyoto str., Kyiv, 02156, Ukraine

ORCID: 0000-0002-3348-8298

Researcher ID: C-1021-2019

Gurzhii Anna,

$\mathrm{PhD}$ (Law Sciences), Associate Professor, Kyiv National University of Trade and Economics, 19, Kyoto str., Kyiv, 02156, Ukraine ORCID: 0000-0001-5757-592X

Researcher ID: M-5511-2016

\title{
UKRAINE ON THE WAY TO MODERNIZATION OF PUBLIC FINANCIAL CONTROL
}

The article revolves around the legal and organizational aspects of public financial control in modern Ukraine. The current state of development of the national public audit system is analyzed. Its positive trends and challenges are highlighted. Based on domestic law achievements, best foreign practices, current national the oretical concepts were formulated practical recommendations, aimed on improvement of the effectiveness of public finance control. It is stated, that implementation of world auditing standards should be recognized as a strategic direction of the national finance policy.

Key words: public funds, budget, financial control, state audit.

Гуржжій Тарас, Гуржій Анна. Украӥна на иляху модернізації державного фінансового контролю.

3 поглибленням європейської інтеграиії, подальшим розвитком національної системи державних фінансів та переходом до міжнародних стандартів державного аудиту набувають особливого значення питання державного фінансового контролю, як ключового інструменту забезпечення законності, правильності та ефективності діяльності накопичення та витрачання державних коштів. Розвиток иього інституту є важливим показником демократизаиії суспільства i, водночас, $\epsilon$ запорукою прозорості та гласності в державній фінансовій діяльності. Незважсаючи на значний прогрес у розвитку державного фінансового контролю в Украӥні, його загальна ефективність залишається низькою. На сучасному етапі розвитку національної системи державних 
фінансів існуе нагальна потреба в удосконаленні правових, організаиійних, економічних та інформачійних засад державного фінансового контролю. Досягнення иієї мети вимагає оновлення існуючої законодавчої бази, створення спеціалізованих веб-ресурсів та інших кроків, спрямованих на підвищення ефективності контролю за накопиченням та витрачанням публічних коштів. Запропоновані кроки покликані сприяти імплементації міжнародних стандартів державного аудиту, розвитку механізмів державного фінансового контролю, підвищення ефективності контролю за накопиченням та витрачанням публічних коштів.

Ключові слова: державні кошти, бюджет, фінансовий контроль, держсавний aydum.

Relevance of research topic. Speaking about problems of filling and using of public funds, it should be mentioned that, regardless of country, their roots always lie in the field of public financial control. On public financial control depend prevention of financial violations, effectiveness of their detection, level of financial discipline, and general results of public financial activities. Effective system of public financial control guarantees effectiveness of financial responsibility. And, on the contrary, poor organization of financial control always leads to increase of financial offences and their latency.

A clear example is modern Ukraine. Not so long ago, our country had quite unsuccessful model of financial control with many disjointed elements, duplication of functions, and purely fiscal orientation. Until the last decade it consisted from a great number of separate audit entities, which functioned without good coordination and interaction. In general it was very ineffective. The number of financial offenses, as well as their level of latency, was almost the highest in Europe.

But, with time Ukraine began transition to standards of good governance and initiated complex reform in financial sphere. Over past years, Ukrainian science and practice had made a number of important steps towards the implementation of world's best audit experience.

Recent researches. A significant contribution to the articulation of of the scientific background for the function and development of Ukrainian state financial control can be found in the works of A. Gurzhii, L. Deshko, N. Novikova, V. Pikhotskii and others.

Presenting main material. In national legislation were transferred important provisions of The Lima and The Mexican Declarations on External Audit (1;2). Main entities of state financial control were redirected from post-audit to pre-audit operations. If earlier their activity was concentrated on revealing financial violations, today their main aim is prevention. For this purpose, subjects of public financial control were given much bigger control powers at stages of budget planning and filling. More and more inspections have preventive character. 
Parliamentary control body (Accounting Chamber / «Rakhunkova Palata») has finally started to control the revenue part of State Budget. Now it's hard to believe, but until recently, Ukraine was the only state among the 170 INTOSAI members, where the Main Control Body had no control over the State Budget planning. And now it has. At the same time there was introduced the system of independent control over the financial activities of the Accounting Chamber as the main external auditor. According to it, such control may be carried out by one of the most experienced audit firm or by one of the leading members of INTOSAI.

In turn, non-parliamentary branch of public financial control has been reorganized. From double (Government and Presidential) dependence, it was transferred under complete Government control.

Total number of control bodies was greatly reduced. As well was optimized their structure. In 2016 was founded The State Audit Service of Ukraine, the central executive body, responsible for formation and implementation of state policy in the field of financial control.

During last years was substantively improved tlegal regulation of financial control. In particular, were adopted: the Law «On Extension of Constitutional Powers of Accounting Chamber»; - a new Law «On the Basic Principles of State Financial Control in Ukraine»; - a new Law «On Accounting Chamber» etc.

Besides, there was greatly expanded the influence of civil society. In the structure of most audit entities were integrated Public Councils - civil bodies for monitoring transparency of audit activities.

So, as a whole, it can be stated that Ukrainian system of public financial control is developing in line with general world trends. But, despite of this, national system of public financial control is still far from perfectness. It is still difficult to call it balanced and harmonic. Its development is too slow. Its organizational, legal and methodical support is too poor comparing with leading European states.

Serious problems take place at all levels of financial control system. The most sensitive of them are the next.

Despite significant reduce of financial control entities in recent years, their system remains very complicated. Along with dozens of internal control units, it includes a large number of external control entities: the Accounting Chamber, the State Audit Service of Ukraine, the State Treasury Service of Ukraine, the State Fiscal Service of Ukraine, the National Bank of Ukraine, the State Commission on Securities and Stock Market, State Property Fund of Ukraine and others.

Most of them were established eventually, without clear plan. Their development is not agreed, their activities are not coordinated. As a result, existing system of audit entities is quite imbalanced. Their competence, functions and frames of responsibility sometimes are overlapping. Quite often, this leads to management 
conflicts, duplication of audits, unreasonable waste of resources. As a whole, it should be noted that modern Ukraine faces negative situation, when, on the one hand, it has significant number of controlling entities, and on the other - there is no good interaction between them (3, p. 288).

Unlike most European countries, Ukraine has no Supreme Audit Institution, providing methodic support and coordination of all controlling entities. At present, Ukrainian system of public financial control covers two organizational subsystems: the Parliamentary (Accounting Chamber) and the Governmental - consisted from wide range of executive bodies and units.

Without central coordination link, all these bodies provide parallel activities both at the national and local levels. Often this leads to organizational «overlays», unreasonable audits, different decisions in same cases and so on. Such situation demands creation of strong coordinating center, which would solve all administrative contradictions and provide tight interaction between all audit entities (4, p. 7-8).

The best way of solving this task is giving to Accounting Chamber the status of Supreme Audit Institution with wide spectrum of coordinating, organizational and methodical functions. By the way, creation of Supreme Audit Institution follows from the provisions of Association Agreement between Ukraine and the EU (5). In the light of this, modern Ukraine has only one choice - to transform Accounting Chamber into Supreme Audit Institution as soon, as it possible.

The next problem is the absence of Basic Law on Public Audit. In modern Ukraine there is no single Law, defining status of all audit services, regulating relations between auditors and audited entities, establishing responsibility and independence of audit institutions (6). The Law of Ukraine «On Basic Principles of State Financial Control in Ukraine» defines the status of only one control institution The State Audit Office of Ukraine (central executive body, responsible for implementation of state policy of financial control).Activities of all the restauditorsare regulated by a wide range of disparate acts, which are full of collisions and duplications (7, p. 152).

At the same time, there is no legal basis for external audit of financial activities provided by State Audit Office of Ukraine. As well, there is no legal basis foraudit of EU funds and grants, state (regional) programs, investment projects, internal audit systems and many other activities, related to filling and using of public funds. Today in Parliament, there are some drafts of the Laws on Public financial control, but any of them is good enough to be accepted at nearest time $(8 ; 9)$.

Despite the fact that national system of financial control generally meets the principles of Lima Declaration, still it is partly based on Soviet traditions. Today, it is generally aimed at checking legality and correctness of using public funds. Instead, social results of public financial activities are not fully analyzed (10, p. 48). According 
to current legislation Ukrainian Accounting Chamber should provide not only financial audit, but also audit of efficiency. But providing it, Accounting Chamber uses only organizational and economical criteria. It does not check any social results of financial activity. So, in this case audit of efficiency is treated as audit of economical (not social!) efficiency.

And this is not surprising since in Ukraine there no clear criteria for measuring social effectiveness. As well, there are not defined legal consequences of poor social results of financial activity. In other words, auditors don't know what to do in cases where financial activity of public administration is economically productive, but socially ineffective.

In addition, if Lima Declaration spreads audit of efficiency upon entire administrative system, current Ukrainian legislation narrows it to the level of separate entities. As a result, comprehensive analysis of public financial management is not provided. And that makes impossible to define the effectiveness of national financial policy. In solving this issue can be useful Sweden experience. In this country audit of efficiency is provided at three levels: national, regional and level of separate entities. Two main efficiency indicators (economic performance and social performance) are measured on wide range of criteria. At the same time, those aspects of public financial activity, which are economically effective (profitable) but ineffective socially, can't be approved.

Despite the expansion of Accounting Chamber powers, its activities at the local level are still limited. Today in Ukraine there are only seven territorial departments of Accounting Chamber. Most of them provide audit in 2, 3, 4and even - in 6 regions at once. At the same time, they consist of only 3 subdivisionswith very small staff. In fact, they are not able to perform audit functions effectively.

The above mentioned transition from the post-audit to pre-audit proceeds too slowly. Most of Ukrainian audit entities received legal powers to carry out previous and current financial audits, but at the same time they were not supplied by necessary methodics. As a result, they still prefer post-fact audit. Preliminary and ongoing audits are carried out only occasionally, and their influence on public financial activities is very weak.

A strong factor of insufficient effectiveness of public financial control in modern Ukraine is the low level of responsibility of audited entities. For example, according to Ukrainian legislation, concealing unproductive losses, making false data to financial statements, interrupting audit inspections and other similar offenses, carry an administrative penalty of 4,5 to 8 Euros. As it clearly seen, such penalty is miserable comparatively to possible profit from financial offences. In the light of this, some executives very easily violate the requirements of financial discipline. 
Despite the fact that in recent years Ukraine has taken a number of steps on implementation world audit standards, this process is far from complete.

In particular, Ukrainian legislation don't not reflect INTOSAI directives about: - creation of Supreme Audit Institution; - giving to it legislative initiative; - creation of coordination center for state audit entities; - improving audit of missions abroad; - independent monitoring of implementation audit recommendations etc.

An important issue of state financial control is its informational and software support. To date, Ukrainian system of public financial control has no informational link. Data exchange between different audit services is poor due to usage of various not adapted software products. Besides, they face such problems as: - non-compliance of information resources; - the lack of unified coding system; - the absence of universal software and so on.

Conclusion. Summarizing all said above, we must state the diversity and complexity of problems related to public financial control in modern Ukraine. They are conditioned by many negative factors and are given at all levels of public administration: national, sectoral, regional. So, their solving demands wide complex of legislative, organizational, informational and other measures.

First of them should be the next:

1. In the field of legislative regulation:

- constitutional entrenchment of Accounting Chamber as Supreme Audit Institution (a higher body in system of public financial control); recognition its autonomy in relations with Parliament; ensuring its independence from the authorities; granting to it the right of legislative initiative;

- adoption the Law on Public Financial Control, based on principles of INTOSAI Lima and Mexico Declarations. This Law should clearly define status of all audit entities, their powers and relations, their competence and responsibility;

- detailed revision of national legislation on state financial control for consistency, coherence and compliance with international treaties of Ukraine;

- criminalization such offenses as: non-fulfilment of audit prescriptions, giving to auditors false information, interrupting audit inspections. This step will highly increase punishment of offenders - to whom could be applied arrest, limitation of freedom, prohibition of holding the post, etc.

2. In the field of organizational support:

- reduction the number of external audit entities, strict definition of their competence and areas of responsibility, elimination of duplications in their powers;

- establishing Regional Offices of Accounting Chamber in all regions of Ukraine. Ensuring their autonomy and independence. Proving their personnel, structure and resources to indicators, defined by best world practices; 
- giving to Accounting Chamber the right to audit of all national organizations abroad (now it can audit only diplomatic institutions);

- improving audit of efficiency, based on various social indicators. Such audit should be carried out at the regional and national levels, as well as at the level of separate entities;

- empowering State Audit Office of Ukraine to audit EU funds and grants, state (regional) programs, investment projects and internal control system.

3. In stuffing:

- increase the licensed number of graduates in the field of financial control;

- implementation of professional and educational standards for obtaining bachelor's and master's degree son specialization «Financial Control»;

- maximum involvement of auditors-practitioners into all stages of educational process: from the development of educational programs to final certification;

- setting up regular internal courses for improving auditors' qualification.

4. In the field of methodical support:

- completing unification of audit terminology in accordance with INTOSAI standards;

- implementation best European methods of financial audit, audit of efficiency, expertise, analysis and other control measures;

- defining criteria for economic and social efficiency of public financial activity, recognizing social efficiency as a main factor of audit evaluation.All financial activities which are economically effective (profitable) but socially ineffective, shouldn't be approved.

5. In information and communication:

- development of the Information-Analytical System of State Financial Control (IASSFC), which would ensure the access of all auditors to: - regulatory framework of public financial control; - information on planned, provided and implemented control measures (incl. information about objects, subjects, terms and general results of inspections); - modern methods of financial audit and audit of efficiency;

- granting the Information-Analytical System access to all state registers and databases, connected with filling and use of public funds;

- providing automatic interaction between Information-Analytical Systemand existing electronic systems on public funds («Open Budget», «Public Budget», «Single Web Portal for the Use of Public Funds» etc.);

- developmentof unified software for audit operations;

- introduction of integrated system on informational exchange between all audit entities. 


\section{REFERENCES}

1. ISSAI 1 - The Lima Declaration Approved at IXth Congress of INTOSAI, Lima/Peru 1977, http://www.intosai.org/issai-executive-summaries/view/article/issai1-the-lima-declaration.html

2. ISSAI 10 - The Mexico Declaration on SAI Independence Approved at XIX th Congress of INTOSAI, Mexico 2007, http://www.intosai.org/issai-executivesummaries/view/article/issai-10-the-mexico-declaration-on-sai-independence.html

3. Deshko L., Gurzhii A., Berlach A, Radyshevska O. State Audits in Modern Ukraine: Issues, Challenges, Perspectives. Public Policy and Administration. 2019. № 2 (18). P. 281-298.

4. Bardash S., Baraniuk Y. Financial Audit as a Part of State Administration in Ukraine: Condition and Public Need. Baltic Journal of Economic Studies. 2016. № 2 (Vol. 2). P. 5-13.

5. Association Agreement between the European Union and the European Atomic Energy Community and their Member States, of the one part, and Ukraine, of the other part of 27.06.2014. Official Bulletin of Ukraine. 2014. № 75. Vol. 1. P. 83 (Art. 2125).

6. Bohdaniuk I., Kolisnichenko V., Ustymenko O. Audit as a Form of Control of the State Financial Inspection of Ukraine. Baltic Journal of Economic Studies. 2018. № 5 (Vol.4). P. 31-35.

7. Novikova N., Deshko L., Gurzhii A. Leading approaches to modernization of state financial control: a case of Ukraine. 2nd International Conference on Social, Economic and Academic Leadership (ICSEAL 2018). P. 149-156.

8. Gurzhii A. (2017). Publichni konsultatsii: aktualni problemy ta perspektyvy pravovoho rehuliuvannia (Public consultations: topical issues and perspectives of legal regulation). Pravovi horyzonty - Legal horizons, № 5, 74-81.

9. Gurzhii T. Public Consultations in Ukraine: Topical Legal Issues. Rocznik Administracji Publicznej. 2017. № 3. S. 309-318.

10. Pikhotskiy V. \& Rysin V. State Control and Public Audit in the Management of Public Finances. European Cooperation. 2019. № 1. P. 38-51. 